Ann. Biol. anim. Bioch. Biophys., 1978, 18 (1), 149-155.

\title{
The influence of magnesium deficiency on calcium metabolism in the rat
}

\author{
par P. LARVOR, Marie-Lovise LABAT*
}

Station de Physiopathologie de la Nutrition, I.N.R.A., Theix, Saint-Genès-Champanelle, 63110 Beaumont

* Service de Biophysique, C.H.U. St Antoine, 75012 Paris, France.

Summary. Calcium metabolism was studied in magnesium-deficient rats with an isotopic technique. ${ }^{45} \mathrm{Ca}$ was injected intravenously and the blood calcium radioactivity curve was analysed mathematically to compute the kinetics of calcium exchange in the whole body.

No important change was noticed after a 10-day magnesium deficiency; there was a significant reduction of the ratio calcium pool/total calcium output from the pool $\left(P / V_{T}\right)$.

After a 20-day deficiency, we noted a dramatic decrease in the two compartments of exchangeable calcium $\left(-40\right.$ p. 100), and a less important decrease of $V_{T}(-15$ p. 100).

Blood plasma urea level increased during magnesium deficiency, while urea urinary clearance remained normal.

A magnesium deficiency causes a pronounced and durable reduction of blood calcium in most species. The rat is an exception since it normally shows an increase in the level of blood calcium when magnesium is deficient.

The cause of the modification in the blood calcium, in either direction, is not clear. In species in which the concentration of calcium in the blood is reduced, both a decrease in the sensitivity of the bone to parathormone (Larvor et al., 1964 ; Estep ef al., 1969) and a reduction in parathormone secretion (Suh ef al., 1971 ; Anast ef al., 1972) have been suggested. The two hypotheses are not exclusive.

Hyperparathyroidism has been suggested to be a possible mechanism in magnesium-deficient rats with a high level of blood calcium (Mac Manus and Heaton, 1969). However, this does not correspond to the reduction in urinary hydroxyprolin, suggesting a reduction in bone catabolism, observed by the same authors.

Much work has been done on the influence of parathormone, calcitonin, phosphate and vitamin $D$ on blood calcium in magnesium-deficient animals. However, the results are difficult to interpret since the characteristics of calcium metabolism are not well understood in these animals.

In calves deficient in $\mathrm{Mg}$ and hypocalcemia, the study of calcium metabolism by an isotopic method shows little alteration in the calcium pool, but a considerable reduction in bone calcium exchange (Larvor et al., 1964). 
There are no comparable results for rat, in which the opposite reaction (hypercalcemia) is found, although this animal constitutes the most common experimental material for studies of magnesium deficiency.

\section{Material and methods.}

Animals and feeding. - All the rats used were bred in our laboratory from the Sherman strain. Two experiments were performed to study short-term magnesium deficiency (10 days) and medium-term deficiency (20-days). Two groups of 6 animals each, consisting of controls and magnesium-deficients, were used in the experiments. The animals were housed in individual metabolic cages and the controls were pairfed with the magnesium-deficient group.

In the first experiment, 5-week old male rats received a balanced semi-synthetic diet (table 1) for 10 days, containing $30 \mathrm{mg} / \mathrm{kg} \mathrm{Mg}$ for the deficient group to which was added $\mathrm{MgSO}_{4}, 7 \mathrm{H}_{2} \mathrm{O}$ to obtain $1000 \mathrm{mg} / \mathrm{kg} \mathrm{Mg}$ for the control group. Both diets contained $14 \mathrm{~g} / \mathrm{kg}$ Ca and $6.5 \mathrm{~g} / \mathrm{kg}$ P. All concentrations were estimated by analysis. For each animal, the 10-day period was followed by a 3-day balance period with the same feed, which was normal or deficient in $\mathrm{Mg}$. During that time the radioactive tracer was injected as described later.

TABLE 1

Composition $(\mathrm{g} / \mathrm{kg})$ of bosal magnesium-deficient diet

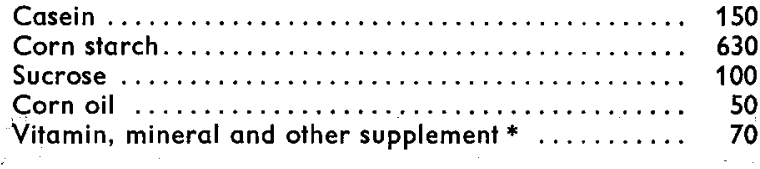

* Supplied per $\mathrm{kg}$ diet : $\mathrm{L}$ cystine $3 \mathrm{~g}$; $\mathrm{L}$ tryptophan $0.5 \mathrm{~g}$; choline chloride $1 \mathrm{~g}$; myo-inositol $300 \mathrm{mg}$; ascorbic acid $100 \mathrm{mg}$; p-aminobenzoïc acid $100 \mathrm{mg}$; nicotinamide $50 \mathrm{mg}$; calcium pantothenate $50 \mathrm{mg}$; $\alpha$-tocopherol $30 \mathrm{mg}$; riboflavin $10 \mathrm{mg}$; thiamin $10 \mathrm{mg}$, phylloquinone $5 \mathrm{mg}$; pyridoxin $5 \mathrm{mg}$; pteroylmonoglutamic acid $1 \mathrm{mg}$; biotin $0.2 \mathrm{mg}$; cyanocobalamin $0.05 \mathrm{mg}$; retinol $1.72 \mathrm{mg}$; cholecalciferol $2.5 \mu \mathrm{g} ; \mathrm{CaCO}_{3} 34 \mathrm{~g}$ (1st experiment) or $18 \mathrm{~g}$ (2nd experiment) ; $\mathrm{KH}_{2} \mathrm{PO}_{4} 13.6 \mathrm{~g} ; \mathrm{NaCl} 10 \mathrm{~g}$; iron ammonium citrate $1.6 \mathrm{~g} ; \mathrm{MnSO}_{4} \mathrm{H}_{2} \mathrm{O} 150 \mathrm{mg} \mathrm{ZnSO}{ }_{4} .7 \mathrm{H}_{2} \mathrm{O} 150 \mathrm{mg}$; $\mathrm{CuSO}_{4} .5 \mathrm{H}_{2} \mathrm{O} 40 \mathrm{mg} ; \mathrm{K} 103 \mathrm{mg} ; \mathrm{Na}_{2} \mathrm{SeO}_{3} 0.2 \mathrm{mg}$.

In the second experiment, the same experimental pattern was followed, except for the duration of deficiency (20 days) and the calcium content of the diet $(6.5 \mathrm{~g} / \mathrm{kg})$.

Isotopic techniques. - At the beginning of the 3-day balance period, isotopic measurements were made using the method of Milhaud et al. (1960). Each animal received an intravenous injection in the caudal vein of ${ }^{45} \mathrm{Ca}$ without carrier $(20 \mu \mathrm{Ci})$; heparinized blood samples were then taken from the retroorbitrary sinus after 2,4 , $6,24,30$ and $48 \mathrm{~h}$. Plasmatic radioactivity was measured by liquid scintillation using a Packard liquid scintillator (Instagel). $10 \mathrm{ml}+10 \mu$ l plasma were pipetted, measured by weight and counted in a Packard 3375 apparatus. 
Analytic techniques. - Feces were dried at $100^{\circ} \mathrm{C}$ for $24 \mathrm{~h}$, weighed and ground ; an aliquot was dry-ashed overnight in a nickel crucible at $450^{\circ} \mathrm{C}$. The ash was dissolved in $0.1 \mathrm{M}, \mathrm{HCl}$.

The levels of magnesium and calcium in the plasma, feed, urine and feces were measured by atomic absorption spectrophotometry (Perkin-Elmer 303) with the techniques described by the Perkin-Elmer Corp. Hydroxyprolin was estimated by the method of Firshein and Shill (1966) in 24-hour urine. During the second experiment, the concentration of urea in plasma and 24-hour urine was determined by a urease technique with a Technicon autoanalyzer.

Statistical analysis. - Results are given as means and standard error of the mean. The significance of difference between means was calculated by Student's test.

\section{Results.}

Clinical and biochemical observations. - The classical clinical effect of $\mathrm{Mg}$ deficiency in the rat, reddening of the ears, was observed 4 to 7 days after the beginning of the experiment. The level of blood magnesium was dramatically reduced during the feeding of magnesium-deficient rations, while blood calcium was higher in deficient rats (table 2, significant for $\mathrm{Ca}$ only after 20 days).

\section{TABLE 2}

Calcium metabolism in control and Mg-deficient rats at 10 or 20 days. Mean of 6 rats + SE, weight in g for rats in $\mathrm{mg}$ for calcium, in $\mathrm{mg} / \mathrm{day}$ for rates, in $\mathrm{mg} / 100 \mathrm{ml}$ for blood plasma $\mathrm{Mg}$ and $\mathrm{Ca}$. The same symbols as in figure 1 are used.

\begin{tabular}{|c|c|c|c|c|c|c|c|c|c|}
\hline $\begin{array}{l}\text { Length of } \\
\text { treatment }\end{array}$ & Treatment & $\begin{array}{l}\text { Live } \\
\text { weight }\end{array}$ & $M$ & $M_{1}$ & $P$ & $\mathrm{~V}_{\mathrm{T}}$ & $v_{1}$ & $\begin{array}{c}\text { Plasma } \\
\mathrm{Mg}\end{array}$ & $\begin{array}{c}\text { inerals } \\
\mathrm{Ca}\end{array}$ \\
\hline \multirow{2}{*}{10 days } & Control .... & $\begin{array}{l}232.2 \\
\pm 3.9\end{array}$ & $\begin{array}{l}28.4 \\
\pm 3.4\end{array}$ & $\begin{array}{l}43.9 \\
\pm 8.9\end{array}$ & $\begin{array}{l}72.2 \\
\pm 9.7\end{array}$ & $\begin{array}{l}72.2 \\
\pm 6.7\end{array}$ & $\begin{array}{l}89.1 \\
\pm 20.1\end{array}$ & $\begin{array}{l}1.63 \\
\pm 0.04\end{array}$ & $\begin{array}{l}11.16 \\
\pm 0.13\end{array}$ \\
\hline & Deficient ... & $\begin{array}{l}222.3 \\
\pm 2.3\end{array}$ & $\begin{array}{l}25.9 \\
\pm 1.5\end{array}$ & $\begin{array}{l}32.6 \\
\pm 1.0\end{array}$ & $\begin{array}{l}58.5 \\
\pm 2.4\end{array}$ & $\begin{array}{l}71.8 \\
\pm 3.2\end{array}$ & $\begin{array}{l}64.4 \\
\pm 4.2\end{array}$ & $\begin{array}{l}0.70 * * \\
\pm 0.01\end{array}$ & $\begin{array}{l}11.53 \\
\pm 0.15\end{array}$ \\
\hline \multirow{2}{*}{20 days } & Control & $\begin{array}{r}214.2 \\
\pm 1.9\end{array}$ & $\begin{array}{l}34.3 \\
\pm 1.7\end{array}$ & $\begin{array}{l}73.7 \\
\pm 8.7\end{array}$ & $\begin{array}{l}108.0 \\
\pm 9.5\end{array}$ & $\begin{array}{l}86.5 \\
\pm 3.6\end{array}$ & $\begin{array}{l}106.7 \\
\pm 4.2\end{array}$ & $\begin{array}{l}1.52 \\
\pm 0.02\end{array}$ & $\begin{array}{l}10.75 \\
\pm 0.06\end{array}$ \\
\hline & Deficient ... & $\begin{array}{l}183.0 * * \\
\pm 3.9\end{array}$ & $\begin{array}{l}25.9 * * \\
\pm 1.6\end{array}$ & $\begin{array}{l}39.5 * * \\
\pm 3.2\end{array}$ & $\begin{array}{l}65.4 * * \\
\pm 3.9\end{array}$ & $\begin{array}{l}73.8 * * \\
\pm 3.7\end{array}$ & $\begin{array}{l}69.7 * \\
\pm 4.0\end{array}$ & $\begin{array}{l}0.44 * * \\
\pm 0.04\end{array}$ & $\begin{array}{l}11.02 * \\
\pm 0.11\end{array}$ \\
\hline
\end{tabular}

Significantly different from control : *P $<0.05 ; * * P<0.01$.

Plasmatic radioactivity curve. - The curve of the decrease in plasma ${ }^{45} \mathrm{Ca}$ radioactivity expressed in counts per minute (cpm) and per $\mathrm{mg}$ of calcium for $10^{6} \mathrm{cpm}$ injected can be represented by the sum of two exponents. This means that the exchangeable calcium in rat can be considered, in a simplified manner, as the two-compartment 
open system already described by Milhaud ef al. (1960). Figure 1 is a diagram of this system.

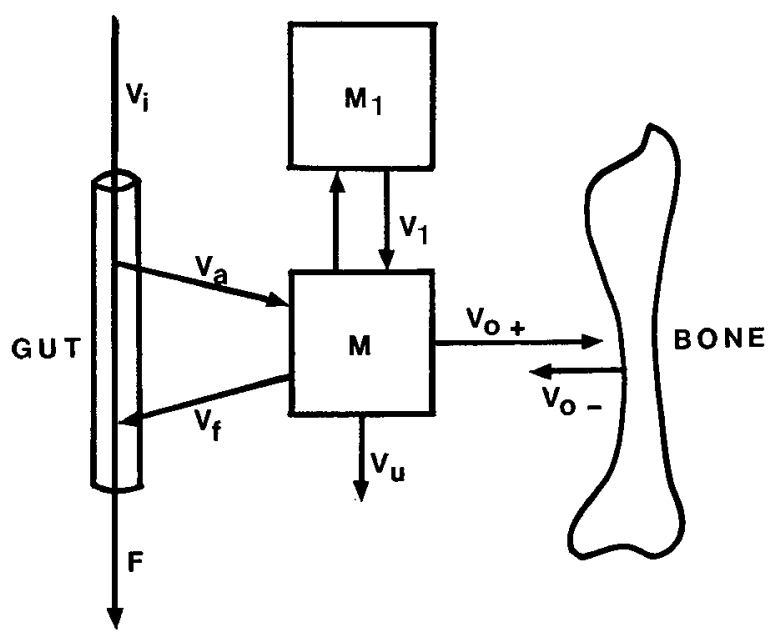

FIG. 1. - Model of rat calcium metabolism, with conventional abbreviations.

$V_{\mathrm{i}}=$ calcium ingested $(\mathrm{mg} / \mathrm{d}) ; \mathrm{V}_{\mathrm{a}}=$ true intestinal absorption of calcium $(\mathrm{mg} / \mathrm{d}) ; V_{\mathfrak{f}}=$ metabolic fecal excretion of calcium $(\mathrm{mg} / \mathrm{d}) ; \mathrm{F}=$ total fecal excretion of calcium $(\mathrm{mg} / \mathrm{d}) ; V_{\mathfrak{u}}=$ urinary excretion of calcium $(\mathrm{mg} / \mathrm{d}) ; \mathrm{V}_{0^{+}}=$bone anabolism, or accretion $(\mathrm{mg} / \mathrm{d}) ; \mathrm{V}_{0^{-}}=$bone catabolism of calcium $(\mathrm{mg} / \mathrm{d}) ; M=$ central compartment of the exchangeable pool of calcium $(\mathrm{mg}) ; M_{1}=$ second compartment of the calcium pool $(\mathrm{mg}) ; P=M+M_{1}=$ total pool of exchangeable calcium ; $V_{1}=$ rate of exchange between $M$ and $M_{1} ; V_{T}=$ total output of calcium from the pool, i.e. $V_{T}=V_{f}+V_{u}+V_{0^{+}}(\mathrm{mg} / \mathrm{d}) ; \Delta=$ calcium balance $(\mathrm{mg} / \mathrm{d})$.

The specific radioactivity (SR) at time $t$ in cpm per $\mathrm{mg}$ of $\mathrm{Ca}$ for an injected radioactivity of $10^{6} \mathrm{cPm}$ with the time expressed in days for the first experiment (10-day deficiency, 6 1/2-week old male rats) was :

Controls $: S R(t)=30507( \pm 5081) \mathrm{e}^{-7.25( \pm 0.81) t}+7754( \pm 1076) \mathrm{e}^{-0.766( \pm 0.086) t}$ Deficients : SR(t) $=31476( \pm 2018) \mathrm{e}^{-6.40( \pm 0.30) t}+7779( \pm 314) \mathrm{e}^{-0.855( \pm 0.026) \mathrm{t}}$

(the standard error of each value is shown in parenthesis). The two curves are not significantly different.

During the second experiment (20-day deficiency, 8-week old rats) the variation in $S R$ was :

Controls $: S R(t)=24913( \pm 1235) \mathrm{e}^{-6.59( \pm 0.22) t}+4594( \pm 453) \mathrm{e}^{-0.581( \pm 0.045) t}$ Deficients : SR(t) $=32465( \pm 2470) \mathrm{e}^{-6.62( \pm 0.22) \mathrm{t}}+6848( \pm 468) \mathrm{e}^{-0.775( \pm 0.024) \mathrm{t}}$

After 20-day $\mathrm{Mg}$ deficiency there was a significant difference in the characteristics of the plasmatic specific radioactivity curve.

Computed calcium metabolism. - Table 2 summarizes the characteristics of calcium metabolism calculated from these equations. The anatomical significance of compartments $M$ and $M_{1}$ is not obvious, but we presume that $M$, the fastest exchangeable 
compartment, is both extracellular and intracellular calcium and that $M_{1}$ is mainly the small fraction of quickly exchangeable bone calcium. Significant differences which appeared only after 20 days included a 40 p. 100 reduction in the pool $P$, affecting both compartments $M$ and $M_{1}$, a similar reduction in $V_{1}$ and a 15 p. 100 decrease in $V_{\mathrm{T}}$. These effects were noticeable after 10 days but were not then significant. Although the weight of the Mg-deficient animals was significantly lower than that of the controls in spite of pair feeding, the differences in calcium metabolism are not due to lower weight for, when considered at equal weight, these differences persist.

Balance data. - Table 3 combines the results of isotopic measurements with those of the calcium balance in order to obtain a quantitative estimate of the principal pathways of calcium metabolism. This global estimate is compared with a number of fragmentary results which are generally considered as representative of a metabolic pathway : daily urinary hydroxyprolin (compared at $V_{0-}$ ) and the accretion of a femur by direct measurement of its radioactivity (compared at $\mathrm{V}_{0^{+}}$).

TABLE 3

Quantitative estimate of the principal pathways of calcium metabolism in control or Mg-deficient rats during 10 or 20 days. Mean of 6 rats $\pm S E$, all results expressed in $\mathrm{mg} /$ day, except the ratio $P / V_{T}$. The same symbols as in figure 1 are used.

\begin{tabular}{|c|c|c|c|c|c|c|c|c|c|c|c|c|}
\hline $\begin{array}{l}\text { Length of } \\
\text { treatment }\end{array}$ & Treatment & $v_{i}$ & $\mathrm{~F}$ & $\mathbf{v}_{\mathbf{u}}$ & $\Delta$ & $v_{f}$ & $\mathbf{v a}_{\mathbf{a}}$ & $\mathbf{v}_{0^{+}}$ & $\mathrm{v}_{0^{--}}$ & $\begin{array}{c}\text { femur } \\
\mathbf{v}_{0^{+}}\end{array}$ & $\begin{array}{c}\text { hydroxy- } \\
\text { prolin }\end{array}$ & $P / V_{T}$ \\
\hline \multirow{2}{*}{10 days } & Control ... & $\begin{array}{l}146.8 \\
\pm 27.4\end{array}$ & $\begin{array}{l}116.5 \\
\pm 22.5\end{array}$ & $\left\{\begin{array}{l}0.60 \\
\pm 0.28\end{array}\right.$ & $\begin{array}{r}29.8 \\
+4.8\end{array}$ & $\begin{array}{r}7.0 \\
+1.1\end{array}$ & $\begin{array}{l}37.0 \\
\pm 5.6\end{array}$ & $\begin{array}{l}64.7 \\
\pm 6.4\end{array}$ & $\begin{array}{r}34.8 \\
\pm 6.9\end{array}$ & $\begin{array}{l}1.73 \\
\pm 0.17\end{array}$ & $\begin{array}{r}0.29 \\
\pm 0.03\end{array}$ & $\begin{array}{l}1.002 \\
\pm 0.097\end{array}$ \\
\hline & Deficient . & $\begin{array}{l}155.5 \\
\pm 8.9\end{array}$ & $\begin{array}{l}127.3 \\
\pm 8.2\end{array}$ & $\begin{array}{l}0.40 \\
\pm 0.26\end{array}$ & $\begin{array}{r}27.8 \\
\pm 3.7\end{array}$ & $\begin{array}{r}9.3 \\
+0.7\end{array}$ & $\begin{array}{l}37.3 \\
\pm 4.1\end{array}$ & $\begin{array}{l}62.2 \\
\pm 3.1\end{array}$ & $\begin{array}{r}34.3 \\
\pm 5.0\end{array}$ & $\begin{array}{l}1.70 \\
\pm 0.10\end{array}$ & $\begin{array}{l}0.20 * \\
\pm 0.02\end{array}$ & $\begin{array}{l}0.816 * \\
\pm 0.14\end{array}$ \\
\hline \multirow{2}{*}{20 days } & Control .. & $\begin{array}{r}65.3 \\
0.7\end{array}$ & $\begin{array}{r}52.0 \\
2.5\end{array}$ & $\begin{array}{l}0.26 \\
0.06\end{array}$ & $\begin{array}{r}12.9 \\
2.6\end{array}$ & $\begin{array}{l}4.3 \\
0.4\end{array}$ & $\begin{array}{l}17.6 \\
2.5\end{array}$ & $\begin{array}{l}82.0 \\
3.6\end{array}$ & $\begin{array}{l}69.1 \\
2.7\end{array}$ & $\begin{array}{l}3.58 \\
0.28\end{array}$ & $\begin{array}{l}0.42 \\
0.02\end{array}$ & $\begin{array}{l}1.248 \\
0.095\end{array}$ \\
\hline & Deficient & $\begin{array}{l}50.2 * * \\
\pm 4.6\end{array}$ & $\begin{array}{r}44.8 \\
\pm 5.5\end{array}$ & $\begin{array}{l}0.07 * * \\
\pm 0.01\end{array}$ & $\begin{array}{r}5.1 \\
+3.2\end{array}$ & $\begin{array}{r}3.9 \\
\pm 0.2\end{array}$ & $\begin{array}{l}9.2 * \\
\pm 3.0\end{array}$ & $\begin{array}{l}69.9 * * \\
\pm 3.9\end{array}$ & $\begin{array}{r}64.8 \\
+\quad 2.4\end{array}$ & $\begin{array}{l}2.52 * * \\
\pm 0.13\end{array}$ & $\begin{array}{r}0.36 \\
\pm 0.03\end{array}$ & $\begin{array}{l}0.886 * * \\
\pm 0.025\end{array}$ \\
\hline
\end{tabular}

Significantly different from control : *P $<0.05, * * P<0.01$

After a deficiency of 10 days, there is a significant reduction in the $P / V_{T}$ ratio and in the urinary hydroxyprolin. The urinary excretion of calcium in $\mathrm{Mg}$-deficient animals, which was not significantly reduced after 10 days, diminished significantly after 20 days. There is an increase in urea in the blood plasma during the feeding of a Mg-deficient dief (controls $21.1 \pm 1.1$, deficient animals after 20 days $31.2 \pm 2.0$ $\mathrm{mg} / 100 \mathrm{ml}$ ), but the same is true for daily urea excretion, and the urea clearance is not significantly different (controls $20.0 \pm 1.3 \mathrm{ml} \cdot \mathrm{mn}^{-1} \cdot \mathrm{m}^{-2}$, deficient animals $18.0 \pm 2.0 \mathrm{ml} \cdot \mathrm{mn}^{-1} \cdot \mathrm{m}^{-2}$. 


\section{Discussion.}

The value of the techniques used was tested by comparison between two methods of measurement. The correlation between accretion calculated for the whole skeleton by Milhaud's method $\left(V_{0^{+}}\right)$and femur accretion was $r=0.76(P<0.01)$, which indicates a satisfactory correspondance between the two estimations. The correlation between bone catabolism $\left(V_{0}-\right)$ and urinary hydroxyprolin is slightly lower $(r=+0.71$, $P<0.01)$ as a result of different errors : the $V_{0}$ - measurement is obtained by difference between $\mathrm{V}_{0^{+}}$and balance ; total collagen catabolism, and not only that of the bones, is estimated for hydroxyprolin.

These results show that magnesium deficiency in the rat causes a considerable reduction in the pool of exchangeable calcium in the two compartments in addition to the well known increase in blood calcium. There is also a parallel reduction in the rate of exchange of the two compartments and less reduction in the overall rates of calcium loss from the pool $\left(\mathrm{V}_{\mathrm{T}}\right)$ and of bone exchange.

The differences become significant only after 20 days of deficiency. They differ notably from those described previously in calves (Larvor ef al., 1964) in which the blood calcium level and bone calcium exchange decrease considerably, but there is only a slight decline in the pool of exchangeable calcium. Whereas in rat, the $P / V_{T}$ ratio is reduced after only 10-day deficiency, in calves this ratio is clearly increased. However, these observations do not explain why in rat there is an increase in blood calcium with a reduced exchange pool, and in calves a decrease in blood calcium also with a subnormal exchange pool. It is only clear that the accessible compartment (plasma calcium) varies independently of cellular calcium in both cases.

More specifically, the increase in blood calcium in rat cannot be attributed only to an increase in intestinal resorption of calcium. Although this has been reported during magnesium deficiency (Mac Manus and Heaton, 1969), it was not observed in the present experiments.

These results provide some information about the action of various modifiers of calcium metabolism when injected into Mg-deficient rat (Miravet ef al., 1976). Earlier it was reported (Rayssiguier and Larvor, 1974) that injection of PTH into such animals caused an increase in blood calcium similar to that observed in controls, while in contrast, a phosphate injection caused a much greater and more lasting reduction of blood calcium in the deficient animals than in controls. Isotopic measurements confirm that bone sensitivity to PTH is reduced in Mg-deficient animals, since if it were normal, the liberation of an equal quantity of bone calcium into the smaller pool would cause a greater increase in blood calcium. The greater and more lasting reduction in blood calcium in Mg-deficient animals injected with phosphates can be explained by the smaller pool and the reduction of the response of bone to endogenous PTH. This explanation does not exclude the possibility that there is also a reduction in the secretion of endogenous PTH.

The increase in blood urea already reported (Rayssiguier et al., 1973) is accompanied by an almost normal clearance of urea. This makes it unlikely that nephrocalcinosis is the cause of the increase in blood urea, at least at an early stage of deficiency, for a reduction in inulin clearance was reported (Ginn and Shanbour, 1967) in rats 
after 5-week deficiency. In contrast it is possible that the increase in the level of urea in the blood results from the predominance of protein catabolism over anabolism and that the polyuria observed in $\mathrm{Mg}$ deficiency (Smith et al., 1962), is linked with the increase in blood urea.

Réunion Groupe Développement INRA/Productions animales Montpellier, 17-18 mai 1977.

Résumé. 1. Le métabolisme du calcium a été étudié chez des rats carencés en magnésium au moyen d'une technique isotopique. Les paramètres cinétiques des échanges de calcium furent calculés par une méthode mathématique, à partir de la courbe de décroissance de la radioactivité de ${ }^{45} \mathrm{Ca}$ injecté par voie intraveineuse.

2. Il n'y avait aucune modification importante après 10 jours de carence, sauf une réduction significative de rapport $P / V_{T}$.

3. Après une carence de 20 jours, on constatait une baisse importante des deux compartiments du calcium échangeable $(-40 \mathrm{p} .100)$ et une baisse moins importante de $V_{\mathrm{T}}(-15$ p. 100).

4. Le taux d'urée sanguine était augmenté au cours de la carence en magnésium, avec une clearance normale de l'urée.

\section{References}

ANAST C. S., MOHS J. M., KAPLAN S. L., BURNS T. W., 1972. Evidence for parathyroid failure in magnesium deficiency. Science, 177, 606-608.

ESTEP H., SHAN W. A., WATLINGTON C., HOBE R., HOLLAND W., TUCKER S. G., 1969. Hypocalcemia due to hypomagnesemia and reversible parathyroid hormone unresponsiveness. J. Clin. Endocr. Metab., 29, 842-848.

FIRSHEIN H. E., SHILL J. P., 1966. The determination of total hydroxyproline in urine and bone extracts. Anal. Biochem., 14, 296-300.

GINN H. E., SHANBOUR L. L., 1967. Phosphaturia in magnesium deficient rats. Amer. J. Physiol., 212, 1347-1350.

LARVOR P., GIRARD A., BROCHART M., 1964. Etude de la carence expérimentale en magnésium chez le veau. Ann. Biol. anim. Bioch. Biophys., 4, 371-382.

Mac MANUS J., HEATON F. W., 1969. The effect of magnesium deficiency on calcium homeostasis in the rat Clin. Sci., 36, 297-306.

MILHAUD G., REMAGEN W., GOMES DE MATOS A., AUBERT J. P., 1960 . Etude du métabolisme. du calcium chez le rat à l'aide de calcium ${ }^{45}$. Rev. franc. Et. clin. biol., 5, 254-261.

MIRAVET L., AYIGBEDE O., CARRE H., RAYSSIGUIER Y., LARVOR P., 1976. Lack of vitamin D action on serum calcium in magnesium deficient rats. 2 nd int. Symp. Magnesium, Montreal (in press).

RAYSSIGUIER Y., LARVOR P., 1974. Parathyroid response to hypocalcemia in magnesium deficient rat. Horm. metab. Res., 6, 91.

RAYSSIGUIER Y., LARVOR P., BARLET J. P., 1973. Etude de l'influence d'un phosphonate de sodium sur le taux rénal de calcium chez le rat carencé en magnésium. C. R. Acad. Sci. Paris, Série $D$, 276, 2035-2038.

SMITH W. O., BAXTER D. J., LINDER A., GINN H. E., 1962. Effect of magnesium depletion on renal function in the rat. J. Lab. clin. Med., 59, 211-219.

SUH S. M., CSIMA A., FRASER D., 1971. Pathogenesis of hypocalcemia in magnesium depletion. J. clin. Invest., 50, 2668-2678. 